\title{
Passive filter design for reducing harmonics in light emitting diode bulb
}

\author{
Rambe Ali Hanafiah ${ }^{1 *}$, Muhammad Safril ${ }^{1}$, and Suherman Suherman ${ }^{1}$ \\ ${ }^{1}$ Universitas Sumatera Utara, Electrical Engineering Department, Medan, Indonesia
}

\begin{abstract}
Harmonics reduce power quality and increase inefficiency. Although light emitting diode (LED) bulb has been considered more efficient than previous bulb technologies; its internal circuits potentially generate additional problems. This paper has surveyed 6 LED bulb samples and measured the harmonics generated by the internal circuits. As a result. 7 Watt type B LED bulb produces the highest 3rd order harmonics current which is incompatible with IEC61000-3-2 Class C. A prototype of LC filter is designed to decrease the harmonic level. The measurement shows that the designed passive filter is able to reduce at least $81.3 \%$ of harmonics.
\end{abstract}

\section{Introduction}

Light emitting diodes (LED) is designed to fulfil the necessity of efficient light bulb as lighting consumes about $20 \%$ of total world energy [1][2]. LED bulb is supplied by electricity source through an AC/DC converter, driving light controller circuits [3]. This flyback circuit as shown in Figure 1, has transformer and capacitor that potentially produce harmonics. The primary coil is to control voltage on fly-back. This bootstrap coil controls the transistor and MOSFET voltages. When starting up. No power produced in bootstrap. Therefore; the start-up regulator such as LR645 and LR8 are employed. After bootstrap produces power, the regulator is off. This fly-back circuit is built in the LED bulb as in Figure 2.

Switching on MOSFET fly-back circuit results electric waveforms which are different from the fundamental one [4]. It results harmonic distortion. Harmonic is defined as a current or a voltage that has frequency folding of its fundamental [5]. These harmonics are unwanted in electrical system. Third harmonic distortion (THDi and THDv) are used to measure harmonic level [6]. In order to comply with IEC61000-3-2 Class C requirement, these harmonics should be reduced. This paper reports harmonic reduction on LED bulb through simulation and implementation.

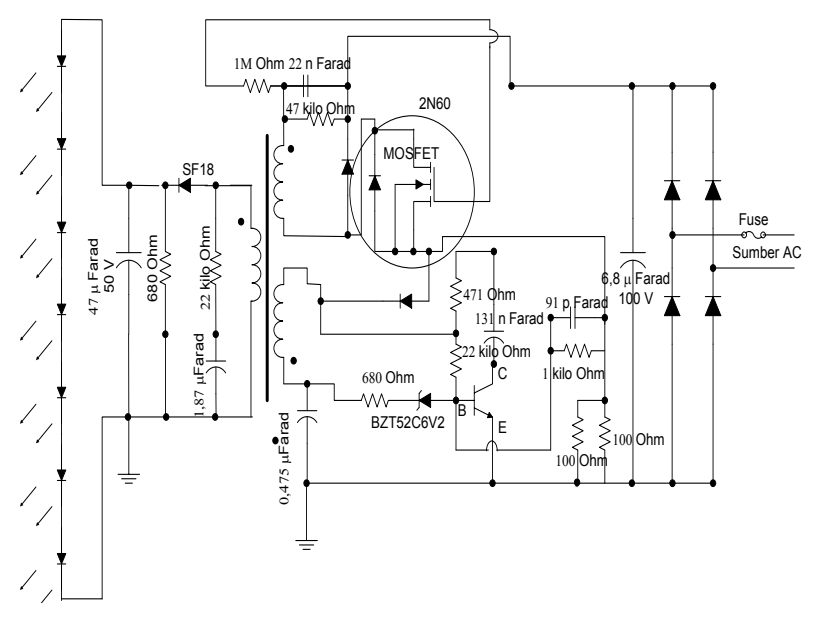

Fig. 1. Fly-back circuit.

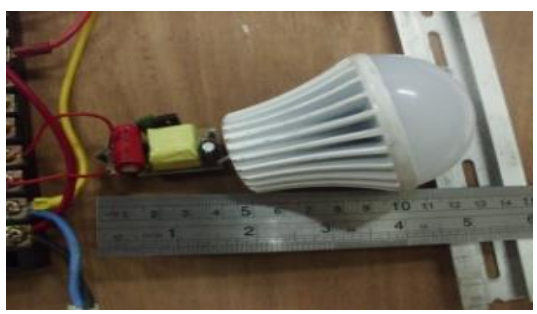

Fig. 2. LED bulb.

\section{Research methods}

Table 1 plots survey results on harmonics generated by the 6 selected LED bulb of 7 Watt. The survey employed power Q fluke 435 and the power logic PM5330 Schneider electric. The harmonic is bigger than the permitted threshold; as standardized by IEC 61000-3-2 class C.

\footnotetext{
* Corresponding author: $\underline{\text { ali3@usu.ac.id }}$
} 
Table 1. Harmonics in LED bulbs.

\begin{tabular}{|l|c|c|c|c|c|c|}
\hline \multirow{2}{*}{ Parameters } & \multicolumn{6}{|c|}{ LED Bulb 7 watt } \\
\cline { 2 - 7 } & $\mathbf{A}$ & $\mathbf{B}$ & $\mathbf{C}$ & $\mathbf{D}$ & $\mathbf{E}$ & F \\
\hline $\begin{array}{l}\text { Phase } \\
\text { Voltage }(V)\end{array}$ & 215.12 & 214.98 & 226.48 & 214.73 & 214.98 & 223.26 \\
\hline $\begin{array}{l}\text { Phase } \\
\text { Current(A) }\end{array}$ & 0.093 & 0.05 & 0.038 & 0.063 & 0.074 & 0.147 \\
\hline $\begin{array}{l}\text { Power(VA) } \\
\text { Active Power } \\
\text { (W) }\end{array}$ & 18.6 & 5.7 & 8.7 & 7.6 & 14.4 & 33.1 \\
\hline $\begin{array}{l}\text { Reactive } \\
\text { Power(VAR) }\end{array}$ & 17.1 & 1.5 & 6.8 & 2.3 & 13.1 & 32.7 \\
\hline $\begin{array}{l}\text { Frequency } \\
\text { (Hz) }\end{array}$ & 50.1 & 50.1 & 50.1 & 50.1 & 50.1 & 50.1 \\
\hline Power Factor & 0.37 & 0.51 & 0.63 & 0.53 & 0.38 & 0.15 \\
\hline THDv & 1.8 & 1.7 & 2 & 1.8 & 1.8 & 2.3 \\
\hline THDi & 37.8 & 154.8 & 98.5 & 145.7 & 44.3 & 30.1 \\
\hline
\end{tabular}

As shown in Table 1, LED B has the highest THDi $154.8 \%$. The third order harmonic is $90.3 \%$, the fifth is $76.1 \%$. The 7 th, 9th, 11th, 13th and 15 th are $58.6 \%$, $42.1 \%, 31 \%, 27 \%$ and $26 \%$. Based on this fact, the designed filter is intended for overcoming harmonics in LED bulb B.

This research performs simulation and implementation of passive filter design. Simulation is to mimic the real situation. Afterward, $\mathrm{L}$ and $\mathrm{C}$ values are calculated. In implementation, inductor is designed by using transformer, creating multiple inductor networks.

The result is then tested by using either simulation or measurement. Figure 3 shows the snapshots of harmonic values generated by LED bulb $B$ which is used as the basic of LC filter design. Figure 4 represents the system in simulation.

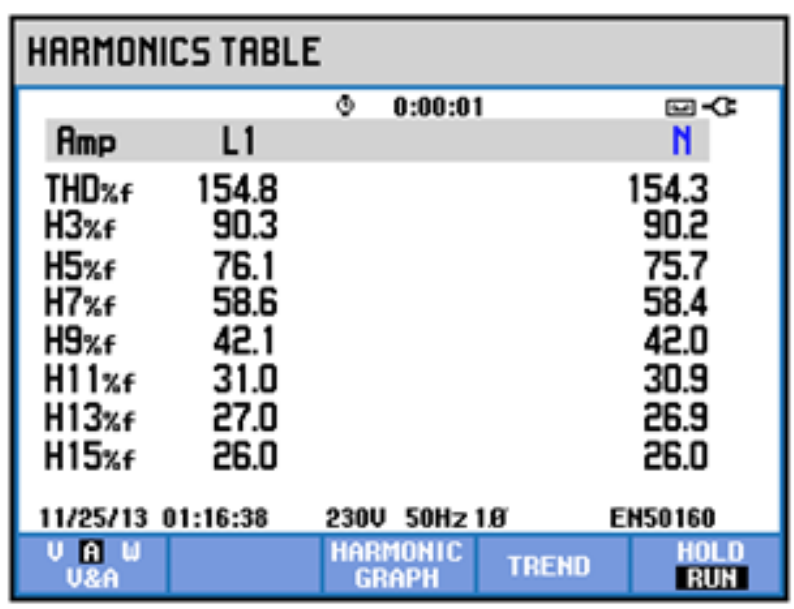

a. Current harmonics snapshot

\begin{tabular}{|c|c|c|c|c|}
\hline \multicolumn{5}{|c|}{ HARMONICS TRBLE } \\
\hline Volt & L1 & (5) $0: 00: 06$ & & 四 \\
\hline $\begin{array}{l}\text { THD\%f } \\
\text { H3\%f } \\
H 5 \% f \\
H 7 \% f \\
H 9 \% f \\
H 11 \% f \\
H 13 \% f \\
H 15 \% f\end{array}$ & $\begin{array}{l}1.7 \\
0.1 \\
1.7 \\
0.2 \\
0.2 \\
0.1 \\
0.1 \\
0.0\end{array}$ & & & $\begin{array}{r}18.1 \\
8.4 \\
8.6 \\
4.7 \\
0.9 \\
3.3 \\
1.8 \\
1.7\end{array}$ \\
\hline \multicolumn{2}{|c|}{ 11/25/13 01:16:34 } & $230 \mathrm{U} 50 \mathrm{~Hz}$ & & EH50160 \\
\hline 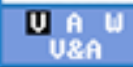 & & $\begin{array}{l}\text { HARMOHIC } \\
\text { GRAPH }\end{array}$ & TREHD & $\begin{array}{l}\text { HOLD } \\
\text { RUH }\end{array}$ \\
\hline
\end{tabular}

b. Voltage harmonics snapshot

Fig. 3. Snapshots of LED B Harmonics.
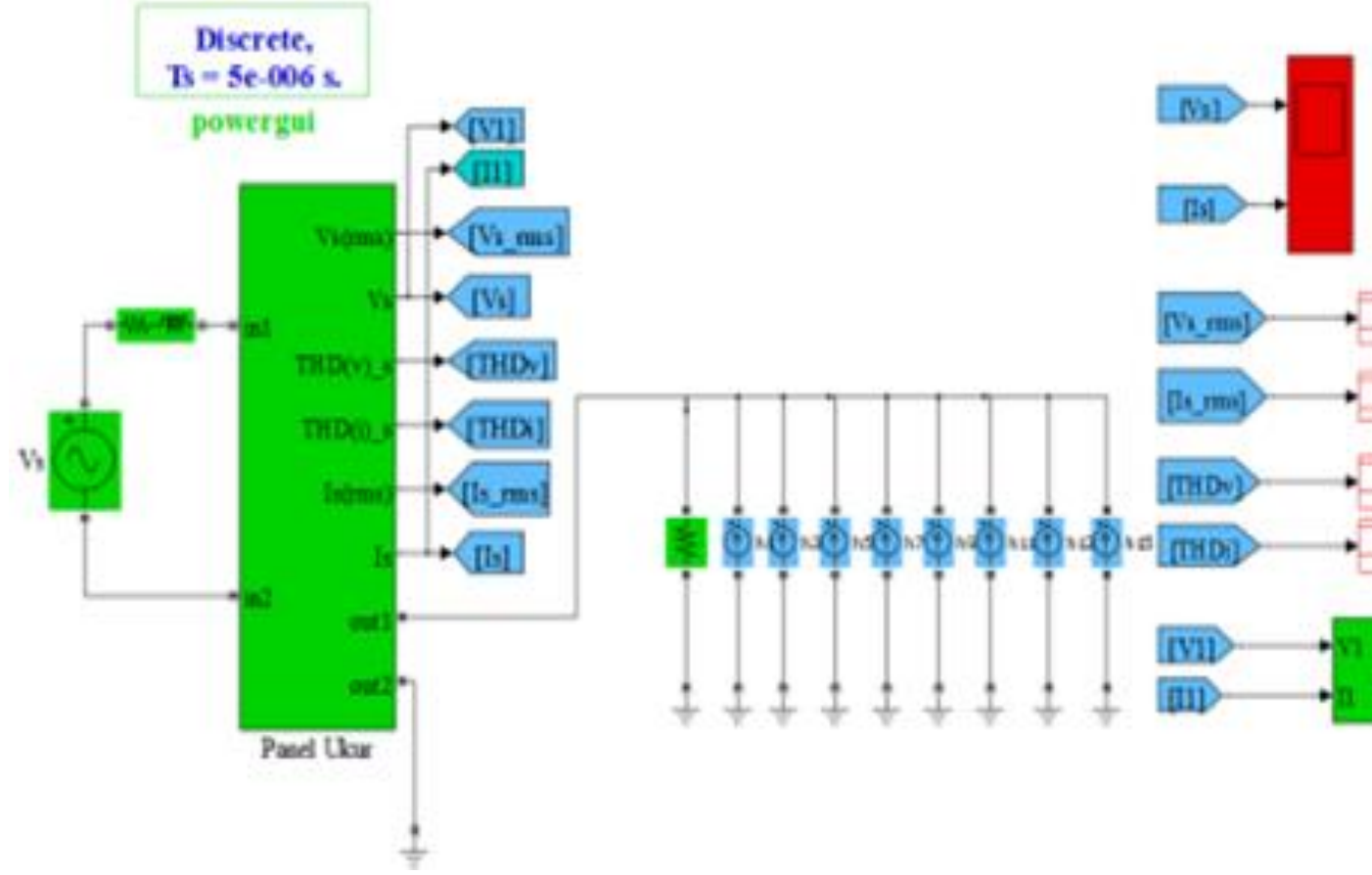

Fig. 4. Simulation model. 
By using data on Figure 3, the load current is calculated by using:

$$
I=\frac{5.5 \mathrm{Watt}}{214.98 \mathrm{Voltx} 0.51}=0.05 \mathrm{~A}
$$

The power consumed for power factor 0.51 is:

$\mathrm{P}=214.98 \times 0.05 \times 0.51=5.48 \propto 5.5 \mathrm{watt}$

If it is assumed that power factor is corrected to 0.98 , the load current is:

$$
I=\frac{5.5 \text { Watt }}{214.98 \text { Voltx } 0.98}=0.026 \mathrm{~A}
$$

The capacitor is calculated by using:

$$
Q_{C}=P\left(\tan \varphi_{\text {awal }}-\tan \varphi_{\text {target }}\right)
$$

$Q_{C}=5.5\left(\tan 59.34^{\circ}-\tan 11.48^{\circ}\right)$

$Q_{C}=5.5(1.69-0.2)$

$Q_{C}=5.5(1.49)=8.16 \mathrm{VAR}$

The capacitor value for 8.16 VAR is:

$$
\begin{gathered}
X c=\frac{V^{2}}{Q_{c}}=\frac{(214.98)^{2}}{8.16}=5664.07 \Omega \\
C=\frac{1}{2 \pi \times 50 \times 5664.07}=0.562 \times 10^{-6} \mathrm{~F}=0.562 \mu \mathrm{F}
\end{gathered}
$$

The inductor is calculated as:

$$
Z=\frac{214.98}{0.05}=4285.52 \Omega
$$

and:

$$
X_{L}=\frac{4285.52}{3^{2}}=476.17 \Omega
$$

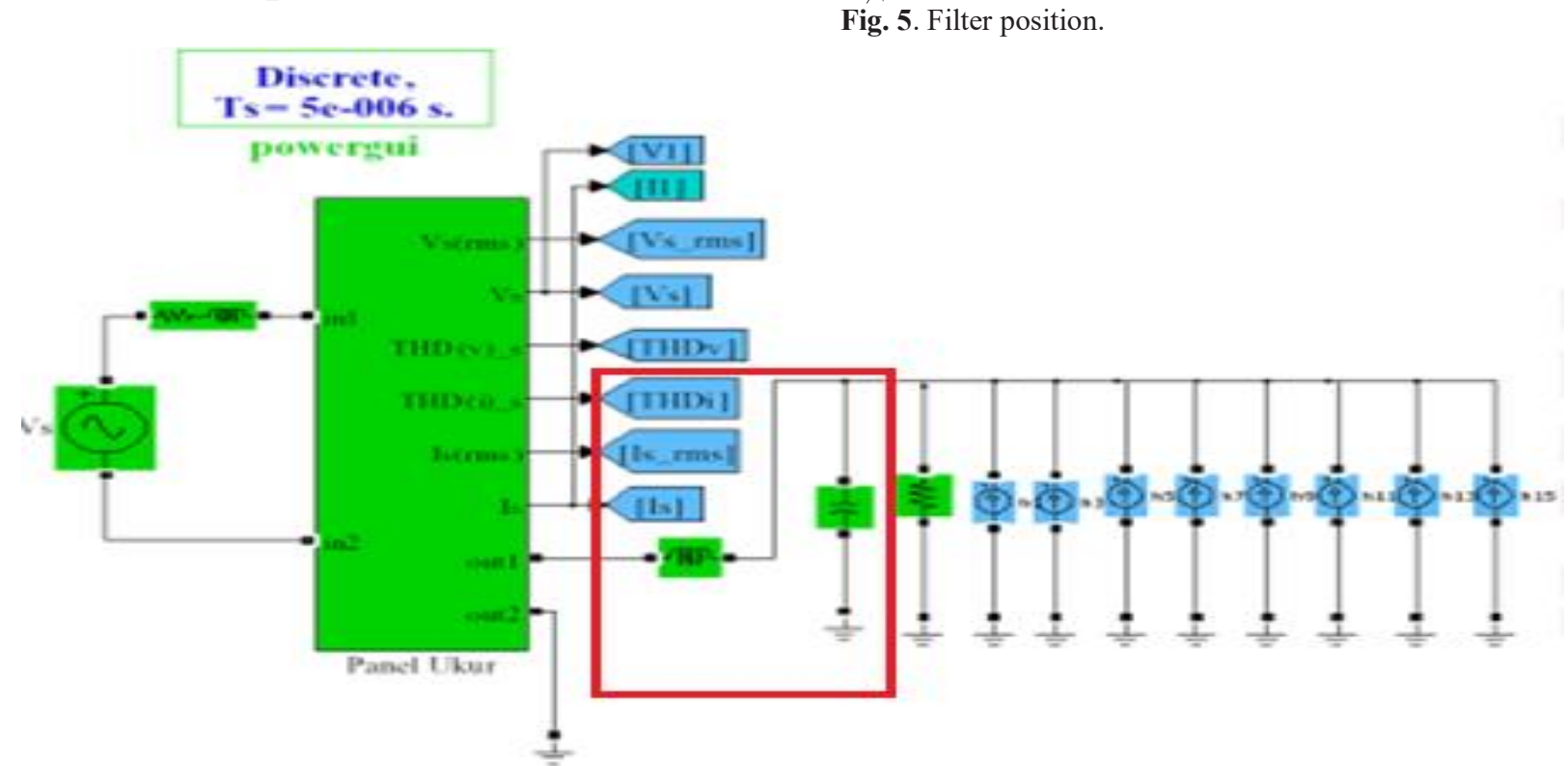

Based on harmonics orde:

$$
X_{n}=3 \times 476.17=1428.5 \Omega
$$

Then:

$$
R=\frac{1428.5}{100}=14.29 \Omega
$$

The inductor $(\mathrm{L})$ is:

$$
L=\frac{\sqrt{(4285.52)^{2}+(14.29)^{2}}}{2 \pi \times 50}=13.64 \mathrm{H}
$$

This value is then examined by applying this LC to system model in Figure 4 and implemented by using real circuit.

\section{Simulation results}

By locating the calculated LC parallel to the system model on Figure 4, the harmonic reduction can be analysed. The filter position is illustrated in Figure 5 and simulation model is depicted in Figure 6.

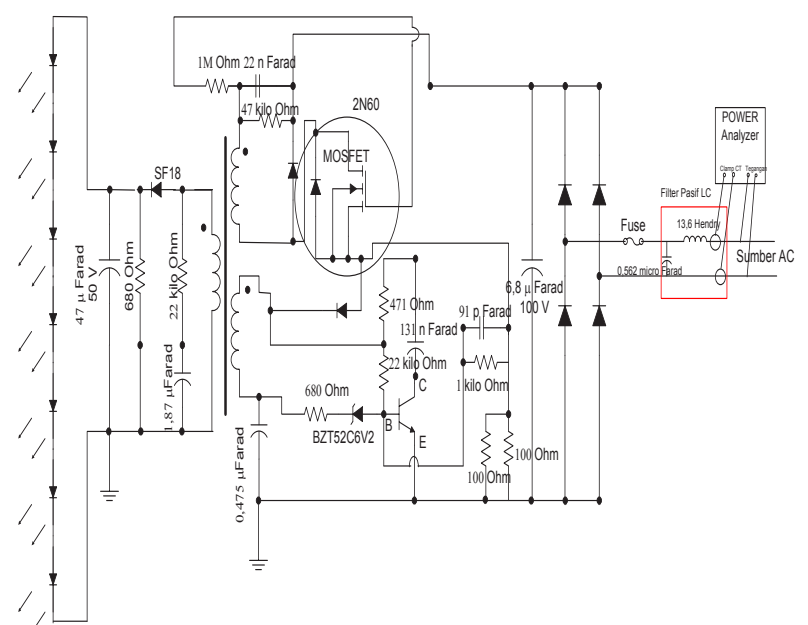

Fig. 5. Filter position.

Fig. 6. Filter insertion on model.

\footnotetext{
*Corresponding author: ali3@usu.ac.id
} 
Simulation shows that the inserted LC filter is able to reduce harmonics values as outline in Table 2.

Table 2. Simulation results.

\begin{tabular}{|c|c|c|}
\hline Parameter & Before & After \\
\hline Phase Voltage (V) & 214.98 & 214.97 \\
\hline Phase Current(A) & 0.06 & 0.03 \\
\hline Power Factor & 0.51 & 0.98 \\
\hline THDv & 1.7 & 0.17 \\
\hline THDi & 154.8 & 13.91 \\
\hline Frequency $(H z)$ & 50 & 50 \\
\hline Orde-1 & 100 & 100 \\
\hline Orde-3 & 95.28 & 13.12 \\
\hline Orde-5 & 80.29 & 4.23 \\
\hline Orde-7 & 61.81 & 1.69 \\
\hline Orde-9 & 44.39 & 0.74 \\
\hline Orde-11 & 32.67 & 0.36 \\
\hline Orde-13 & 28.44 & 0.23 \\
\hline Orde-15 & 27.37 & 0.16 \\
\hline & & \\
\hline
\end{tabular}

\section{Implementation results}

Capacitor is easily found in market. However, inductor is tricky to design. In order to produce $13.64 \mathrm{H}$ inductor, the size and number of turn are calculated as follows:

$$
\begin{gathered}
b=\sqrt[s]{\frac{1,5 \times 5,5}{9,9}}=0,95 \\
h=\frac{0,95}{0,6561}=1,43 \mathrm{~cm}
\end{gathered}
$$

The surface area is:

$$
\mathrm{A}_{\mathrm{c}}=\mathrm{b} \times \mathrm{h}=0,95 \times 1,43 \mathrm{~cm}^{2}
$$

The designed inductor consist of 8 inductor of $1.7 \mathrm{H}$ made of transformer. For each inductor, number of turn is:

$$
n_{3}=\frac{1_{2} 7 \mathrm{H} x 0,05 \mathrm{~A}}{1_{\imath} 2 \text { Tesla } x 1_{2} 35 \mathrm{~cm} 2} \times 10^{4}=526 \text { turns }
$$

Turn diameter is:

$$
d=\sqrt{\frac{4}{\pi} x \frac{0,05 \mathrm{~A}}{5 a \mathrm{amp} / \mathrm{cm} 2}}=0,1 \mathrm{~mm}
$$

The air gap is:

$$
L_{g}=\frac{0,000001256 x 1_{2} 7 x(0,05)^{2}}{(1,2)^{2} x 1_{3} 35} \times 10^{4}=2,75247 \times 10^{-5}
$$

Its realization is shown in Figure 7.

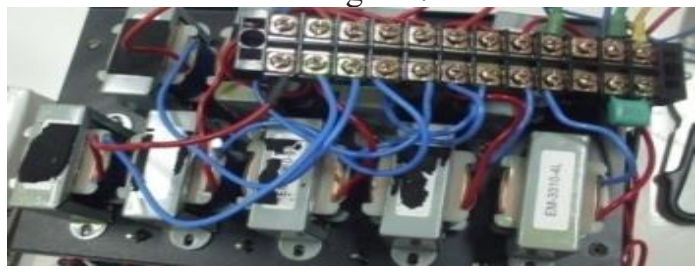

Fig. 7. Filter implementation.
The harmonics value after measuring the implemented filter is shown in Table 3.

Table 2. Simulation results.

\begin{tabular}{|l|l|l|}
\hline \multicolumn{1}{|c|}{ Parameter } & \multicolumn{1}{c|}{ Before } & \multicolumn{1}{c|}{ After } \\
\hline Phase Voltage (V) & 214.98 & 214.98 \\
\hline Phase Current(A) & 0.06 & 0.06 \\
\hline Power Factor & 0.51 & 0.51 \\
\hline THDv & 1.7 & 1.7 \\
\hline THDi & 154.8 & 154.8 \\
\hline Frequency (Hz) & 50 & 50 \\
\hline Orde-1 & 100 & 100 \\
\hline Orde-3 & 95.28 & 90.3 \\
\hline Orde-5 & 80.29 & 76.1 \\
\hline Orde-7 & 61.81 & 58.6 \\
\hline Orde-9 & 44.39 & 42.1 \\
\hline Orde-11 & 32.67 & 31 \\
\hline Orde-13 & 28.44 & 27 \\
\hline Orde-15 & 27.37 & 26 \\
\hline
\end{tabular}

The comparison harmonics in LED bulb, simulation with LC filter and measurement with LC filter is shown in Figure 8.

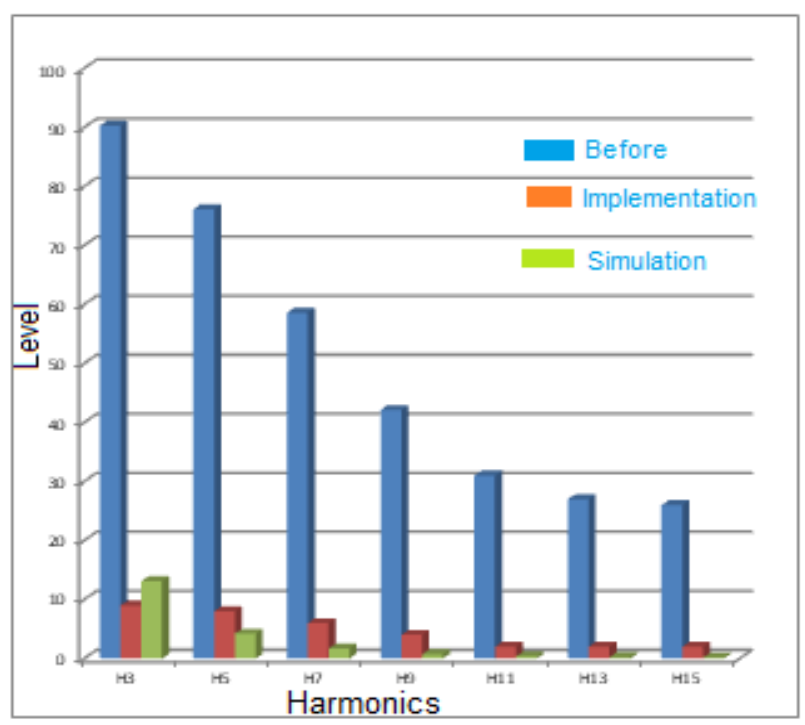

Fig. 8. Performance comparison.

Based on Figure 8, by adding LC filter with $\mathrm{C}=0.562$ $\mu \mathrm{F}$ and $\mathrm{L}=13.64 \mathrm{H}$ is simulation model, the total current harmonics (THDi) is reduced $91 \%$ and average individual harmonic current decreases to $96.3 \%$.

By implementing the LC filter uses capacitor and transformer; THDi decreases THDi up to $89.80 \%$ and average individual harmonic current (IHDi) $91 \%$.

\section{Conclusions}

It has been shown that even LED bulb is design to efficiently using the electricity; its internal circuit produces harmonics. By proposing a simple LC filter, the THDi and IHDi are successfully reduced. The simulation show that LC filter produces 91\% THDi and average individual harmonic current decreases to $96.3 \%$ while real implementation gives THDi $89.80 \%$ and IHDi $91 \%$.

\footnotetext{
*Corresponding author: ali3@usu.ac.id
} 


\section{References}

1. S. Bakhtiar, B., Suherman, Realisasi Sistem Switch Lampu Penerangan Ruangan Otomatis Untuk Meningkatkan Efisiensi Energi Listrik., J. Arus Elektro Indones., vol. 1, no. 2, (2015)

2. E. Mubarakah, N., Al-Hakim, M. Y., Warman, "Energy consumption model on WiMAX subscriber station.(2018, February). Energy consumption model on WiMAX subscriber station. In IOP Conference Series: Materials Science and Engineering (Vol. 309, No. 1, p. 012002). IOP Publishing, Energy Consum. Model WiMAX Subscr. Station. IOP Conf. Ser. Mater. Sci. Eng., vol. 309, no. 1, p. 12002, (2018)

3. W. R. Caberos, A. B., Huang, S. C., Gumera, X. D. G., Liou, Hybrid controller for AC-DC power factor correction converter, in Power Electronics Conference (SPEC), IEEE Annual Southern, pp. 15, (2016)

4. M. Khalilian, H., Farzanehfard, H., Adib, E., Esteki, Analysis of a New Single-Stage SoftSwitching Power-Factor-Correction LED Driver With Low DC-Bus Voltage, IEEE Trans. Ind. Electron., vol. 65, no. 5, p. 3858-3865., (2018)

5. M. H. Gil-de-Castro, A., Rönnberg, S. K., Bollen, Light intensity variation (flicker) and harmonic emission related to LED lamps, Electr. Power Syst. Res., vol. 146, p. 107-114., 2017.

6. P. S. Renugadevi, R., Manoharan, Analysis of EOT characteristics of LED lamps., in International Conference on Advances in Electrical Engineering (ICAEE), pp. 1-5, (2014) 